\title{
Modelling Methionine Requirements of Fast- and Slow-Growing Chinese Yellow-Feathered Chickens during the Starter Phase
}

\author{
Long Li ${ }^{1,2, \dagger}$, K.F.M. Abouelezz $2,3,+\oplus$, Zhonggang Cheng ${ }^{2}$, A.E.G. Gad-Elkareem ${ }^{3}$, Qiuli Fan ${ }^{2}$, \\ Fayuan Ding ${ }^{2}$, Jun Gao ${ }^{4}$, Shouqun Jiang ${ }^{2, * \mathbb{D}}$ and Zongyong Jiang ${ }^{2, *}$ \\ 1 College of Animal Science, South China agricultural University, Guangzhou 510642, China; \\ leeloong1985@sina.com \\ 2 Institute of Animal Science, Guangdong Academy of Agricultural Sciences, State Key Laboratory of \\ Livestock and Poultry Breeding, Key Laboratory of Animal Nutrition and Feed Science in South China, \\ Ministry of Agriculture, Guangdong Public Laboratory of Animal Breeding and Nutrition, Guangdong Key \\ Laboratory of Animal Breeding and Nutrition, Guangzhou 510640, China; abollez@aun.edu.eg (K.F.M.A.); \\ chengzhonggang@yeah.net (Z.C.); fanqiuli_829@163.com (Q.F.); dingfayuan@163.com (F.D.) \\ 3 Department of Poultry Production, Faculty of Agriculture, Assiut University, Assiut 71526, Egypt; \\ alialmaraghy@yahoo.com \\ 4 Evonik Industries AG Health \& Nutrition, Rodenbacher Chaussee, 463457 Hanau-Wolfgang, Germany; \\ jun.gao@evonik.com \\ * $\quad$ Correspondence: jsqun3100@hotmail.com (S.J.); jiangzy@gdaas.cn (Z.J.) \\ $\dagger$ These authors contributed equally to this work.
}

Received: 21 January 2020; Accepted: 4 March 2020; Published: 6 March 2020

check for updates

Simple Summary: In poultry production, consuming diets with low or excessive methionine levels leads to negative effects on growth performance. The requirements of methionine may differ among the fast and slow-growing breeds; therefore, the optimal dietary methionine level should be estimated for each. In this study, six dietary methionine levels were evaluated to estimate the optimal level for fast and slow-growing yellow feathered chicken breeds. The quadratic polynomial and exponential asymptotic regression showed that the optimal methionine requirements for maximal growth performance were $0.50 \%$ and $0.53 \%$ in the fast-growing breed, and $0.48 \%$ and $0.52 \%$ in the slow growing breed.

\begin{abstract}
Two experiments were carried out to investigate the dietary methionine requirement for fast and slow-growing Chinese yellow-feathered breeds during the starter phase, based on growth variables and regression models. In Experiment 1, a total of 2880 one-day-old Lingnan chicks (fast growing breed) were used to test the methionine requirement from 1 to 21 days of age for males and females separately. Of each gender, 1440 birds were allocated into 6 dietary methionine levels $(0.28 \%$, $0.32 \%, 0.37 \%, 0.43 \%, 0.50 \%$ and $0.63 \%$ ), each with 6 pen replicates of 40 chicks. Experiment 2 had the same design with Guangxi chicks (slow growing breed) from 1 to $30 \mathrm{~d}$ of age. Results indicated that significant nonlinear or quadratic responses to increasing dietary methionine levels were observed in body weight, daily gain, feed intake and feed conversion ratio of both breeds. In summary, the quadratic polynomial regression showed that the optimal methionine requirements for maximal growth performance of Lingnan chickens were $0.52-0.58 \%$ in males, $0.51 \%$ in females, and $0.53 \%$ in mixed genders. The corresponding values for Guangxi breed were $0.53 \%$ in males by quadratic polynomial regression and $0.43 \%$ in females, and $0.48 \%$ to $0.49 \%$ in mixed sexes by exponential asymptotic models.
\end{abstract}

Keywords: amino acids; nutrient requirements; growth indices; modeling; Chinese yellow-feathered chickens 


\section{Introduction}

With the rapid development of economy in China, the second largest worldwide producer of chicken meat, market demands for nutrient-rich and tasty meat have been in continuous increase, which is boosting the industry of Chinese yellow-feathered chickens. The contribution of such chicken type in production has been growing; 3.7 billion birds annually with more than $30 \%$ of whole chicken meat shares in recent years [1]. The indigenous chickens have a recent increase in their commercial importance due to their favorable meat color and flavor, which highlights the need for comprehensive studies to enhance their feeding standards. However, only few researches on their nutrient requirements were conducted up till now [2-5].

Some essential amino acids are often added as pure to poultry diets to ensure the optimal balance required for poultry in order to maximize the production efficiency. Globally, methionine (Met) is considered to be the first limiting amino acid for poultry fed on typical corn-soybean meal-based diets [6]. Met is an essential amino acid doing numerous vital biological activities in animals' body $[7,8]$; it has an important role in protein synthesis in addition to enhancing the antioxidant capacity of the organism via participating as a precursor of glutathione that eliminates the reactive oxygen species in the body cells $[9,10]$. Additionally, the Met is required for the polyaminase synthesis that mediates cell and nucleus division process, and is considered as the most common donor of methyl group consumed in the DNA methylation process [11-14]. Met, therefore, is required for ensuring normal growth performance in poultry. The dietary supplementation of Met in poultry is commonly used to fulfil the bird requirement of Met and to achieve rapid correction of any deficiency of some nutrients; Met is a precursor of cysteine, succinyl-CoA, creatine, homocysteine and carnitine. Additionally, optimizing the Met level in poultry diets can contribute in reducing the nitrogen emission of nitrogen into the surrounding environment [13,14].

Chinese yellow-feathered chicken is a general name, which consists of quite a few breeds, mainly referring to Chinese local breeds and the improved breeds. Chinese yellow-feathered chickens grow slowly and are reared for a longer time compared with white-feathered broilers. The Lingnan yellow-feathered chicken breed is classified according to its growth rate to fast $(1.47-2.30 \mathrm{~kg}$, marketable at 8-10 weeks), medium (1.00-2.27 kg BW, marketable 9-14 weeks), and slow growing (1.06-1.88 kg BW, marketable 12-25 weeks) $[3,15,16]$. The Guangxi yellow-feathered chicken is a native, slow growing and light-body type breed with good meat quality in China (1.02-1.6kg BW, marketable 13-22 weeks). The nutrient requirements of broilers differ among the different growth stages, which are divided into three periods in Lingnan yellow-feathered broilers: starter (1-21 days old), grower (22-42 days old), and finisher ( $>42$ days), and four phases in Guangxi yellow feathered broilers: starter (1-30 days), grower (31-60 days), early finisher (61-90 days), and later finisher ( $>90$ days old) phases $[15,16]$.

The Met requirement of feeding standard of chicken (CNY/T33-2004) is mainly for mediumgrowing yellow-feathered broilers [12]. As the dietary Met requirement for the yellow-feathered meat type chickens has not been fully determined or optimized, the present study aimed to estimate it for males and females of Lingnan (a typical fast-growing yellow feathered) and Guangxi (a slow-growing yellow-feathered) chicken breeds during the starter period.

\section{Materials and Methods}

\subsection{Birds, Diet and Management}

Two experiments were carried out to estimate the Met requirement for Lingnan (Exp1) and Guangxi (Exp2) yellow-feathered chicken breeds following the same experimental design. Before trial, the Met content of the basal diet ingredients used in both experiments was determined by ion-exchange chromatography on an automatic amino acid analyzer (L8800, Hitachi, Japan), according to the procedures described by $\mathrm{Xi}$ et al. [17]. In each experiment, a total of 2880 one-day-old chicks (50\% males $+50 \%$ females) were randomly assigned to 6 dietary Met levels, each contained 12 identical floor pens of 40 birds, of which 6 pens were males and 6 were females $(n=240$ birds from each 
sex/treatment). The average initial body weights $(\mathrm{g})$ were $33.88 \pm 0.26,38.75 \pm 0.32$, and $36.32 \pm 0.28$ for male, female and mixed sexes of Lingnan chicks, and $31.50 \pm 0.23,31.02 \pm 0.25$, and $31.20 \pm 0.24$ for male, female, and mixed sexes of Guangxi chicks. All birds were housed in one environmentally controlled room with dry wooden shaving flooring, continuous artificial lighting was provided from incandescent lamps, and room temperature was maintained at $30{ }^{\circ} \mathrm{C}$ in the 1 st week and gradually reduced to $25^{\circ} \mathrm{C}$ on the 4 th week. All chicks were managed according to the Animal Care and Use Committee of Guangdong Academy of Agricultural Sciences Management Guide (GAASIAS-2016-017). The experimental diets were offered from $d 1$ to $d 21$ for the Lingnan breed (Exp1) and from $d 1$ to $d$ 30 for the Guangxi breed (Exp2). Dietary treatments included a Met unsupplemented corn-soybean meal basal diet (Table 1) and the basal diets supplemented with $0.04 \%, 0.09 \%, 0.15 \%, 0.22 \%$, and $0.35 \%$ Met in the form of DL-Met (Evonik Industries AG, Hanau-Wolfgang, Germany); the final dietary Met concentrations were $0.28 \%, 0.32 \%, 0.37 \%, 0.43 \%, 0.50 \%$, and $0.63 \%$.

Pelleted feed and drinking water were freely available to chicks. The different diets were prepared three weeks prior to the trial to allow time for checking content homogeneity, in terms of dry matter, ash, crude protein, ether extract, crude fiber, and amino acid concentrations.

Table 1. Composition of the basal diet (air-dry basis, \%).

\begin{tabular}{cccc}
\hline Ingredient (\%) & Amount & Nutrients ${ }^{2}$ & Value \\
\hline Corn & 63.62 & AME $(\mathrm{MJ} / \mathrm{kg})$ & $(12.55)$ \\
Soybean meal & 20.01 & Crude protein $(\%)$ & 21 \\
Pea protein concentrate & 9.68 & Lysine $(\%)$ & 1.2 \\
Soybean oil & 2.56 & Met $^{3}(\%)$ & 0.28 \\
Calcium Carbonate & 1.35 & Cys $^{3}(\%)$ & 0.26 \\
Dicalcium phosphate & 1.9 & Threonine $(\%)$ & 0.84 \\
Mineral premix 1 & 0.20 & Tryptophan $(\%)$ & 0.21 \\
Vitamin premix ${ }^{1}$ & 0.02 & Isoleucine $(\%)$ & 0.89 \\
Salt & 0.49 & Valine $(\%)$ & 0.99 \\
Choline chloride (50\%) & 0.10 & Calcium $(\%)$ & 1.0 \\
L-Threonine & 0.07 & Non-phytate phosphorus $(\%)$ & 0.45 \\
Total & 100 & &
\end{tabular}

${ }^{1}$ Totally provided per kg of diet: $1500 \mathrm{IU}$ vitamin A; $200 \mathrm{IU}$ vitamin D3; $10 \mathrm{IU}$ vitamin $\mathrm{E} ; 0.5 \mathrm{mg}$ vitamin $\mathrm{K} 3 ; 1.8 \mathrm{mg}$ thiamin; $3.6 \mathrm{mg}$ riboflavin; $3.5 \mathrm{mg}$ pyridoxine; $0.01 \mathrm{mg}$ cyanocobalamin; $10 \mathrm{mg}$ pantothenic acid; $30 \mathrm{mg}$ niacin; $0.55 \mathrm{mg}$ folic acid; $0.15 \mathrm{mg}$ biotin; $500 \mathrm{mg}$ choline; $80 \mathrm{mg} \mathrm{Fe;} 8 \mathrm{mg} \mathrm{Cu} ; 80 \mathrm{mg} \mathrm{Mn} ; 60 \mathrm{mg} \mathrm{Zn;} 0.35 \mathrm{mg}$ I; $0.3 \mathrm{mg}$ Se. 2 Values were calculated based on the data provided by Feeding Standard of Chicken (Ministry of Agriculture, China, 2004). ${ }^{3}$ Analyzed values.

\subsection{Growth Performance}

Birds were weighed at the beginning (day 1) and end of each experiment to record the initial and final body weights (FBW), which were used to calculate the average daily gain (ADG). Average daily feed intake (ADFI) was measured on a per pen basis for the entire experimental period, and the feed conversion ratio (FCR) was calculated. Mortality was checked daily and dead birds were weighed in order to adjust the feed intake calculations.

\subsection{Statistical Analysis}

Data were subjected to one-way ANOVA using the GLM procedure of SAS (version 9.3, SAS Inst., Cary, NC, USA, 2014). Tukey-Kramer test was used for means comparison, and pairwise comparisons among the means were assessed by Duncan's multiple-range tests at $p<0.05$. All data were expressed as means and SEM, derived from ANOVA error mean square. When the main effect was significant $(p<0.05)$, linear and quadratic effects of Met content were determined. For key performance variables, the dietary methionine requirement of the birds was estimated using quadratic polynomial (QP) or exponential asymptotic (EA) models by the NLIN procedure of SAS (SAS Institute, 2014). 
QP model:

$$
\mathrm{Y}=\mathrm{c}+\mathrm{bX}+\mathrm{a} \mathrm{X}^{2}
$$

where $\mathrm{a}=$ quadratic coefficient, $\mathrm{b}=$ linear coefficient, $\mathrm{c}=$ intercept. The requirement of Met was defined as Met $=-b /(2 \times a)$.

EA model:

$$
\mathrm{Y}=\mathrm{a}+\mathrm{b} \times(1-\operatorname{EXP}(-\mathrm{c} \times(X-\mathrm{d})))
$$

where $\mathrm{a}=$ relative response to the diet containing the lowest Met (deficient diet); $\mathrm{b}=$ difference between the minimum and the maximum response obtained with dietary Met; $c=$ curve slope coefficient; $d=$ Met level of the deficient diet). The optimal Met was defined as Met $=(-\ln (0.05) / c)+d$, using $95 \%$ of the asymptotic response, since the exponential curve never reaches the asymptotic point [18-20]. The suitability of the different models was evaluated by the correlation coefficient $\left(\mathrm{R}^{2}\right)$, Akaike information criteria (AIC) and mean square error values (MSE).

\section{Results}

\subsection{Growth Performance of Lingnan Broilers Aged 1 to 21 Days (Exp 1)}

The growth performance traits of male, female and mixed male and female Lingnan yellow-feathered chickens fed different dietary Met levels between 1 and 21 days of age are shown in Tables 2-4, respectively. The increase in the dietary Met level showed linear and quadratic effects on the final BW, ADG, ADFI and FCR (linear, $p<0.01$; quadratic, $p<0.01$ ) of males; and final BW, ADG and FCR (linear, $p<0.01$; quadratic, $p<0.01$ ) of females; and final BW, ADG and ADFI (linear, $p<0.01$; quadratic, $p<0.01$ ) of mixed genders. According to the EA and QP regression, the optimal dietary Met level for the highest body weight were $0.54 \%$ and $0.55 \%$ in males, $0.47 \%$ and $0.51 \%$ in females, and $0.50 \%$ and $0.53 \%$ in mixed genders. The corresponding EA and QP values for the highest ADG were $0.54 \%$ and $0.55 \%$ in males, $0.47 \%$ and $0.51 \%$ in females, $0.50 \%$ and $0.53 \%$ in mixed genders. With regard to these results, it is worth mentioning that obtaining the same optimum Met requirement value for maximal final BW and ADG is logically expected; certainly, because these two variables are linearly correlated, where the ADG is calculated as the (final BW-initial BW) /days. This, therefore, led to the same values of R2 and the same calculated Met requirements for these two variables (Tables 2-4, Figures 1-3). Additionally, the EA and QA models showed that the optimal Met level for ADFI were $0.58 \%$ and $0.50 \%$ in males, and $0.51 \%$ and $0.47 \%$ in females, and those of daily feed intake estimated $0.50 \%$ and $0.52 \%$ in males, and $0.52 \%$ and $0.53 \%$ in mixed genders. Goodness-of-fit results for the growth performance functions are shown in Figures 1-3. The high $\mathrm{R}^{2}$, and lowest AIC and MSE values of QP model are shown in Figure $1 \mathrm{~A}-\mathrm{C}$, Figure 2A,B, Figure 3A-C. The results indicated that the QP model is more adequate for predicting the optimal Met requirements for maximal growth performance in Lingnan broilers, which showed that the optimal Met requirements for Lingnan male, female and mixed sexes were $0.52 \%$ to $0.58 \%, 0.51 \%$, and $0.53 \%$, respectively. 
Table 2. Effects of total dietary methionine level on growth performance of male Lingnan yellow-feathered chickens aged 1-21 days.

\begin{tabular}{|c|c|c|c|c|c|c|c|c|c|c|}
\hline \multirow{2}{*}{ Variables } & \multicolumn{6}{|c|}{ Total Dietary Methionine Levels (\%) } & \multirow{2}{*}{ SEM $^{1}$} & \multicolumn{3}{|c|}{$p$-Value } \\
\hline & 0.28 & 0.32 & 0.37 & 0.43 & 0.50 & 0.63 & & Met Level & Linear & Quadratic \\
\hline Final body weight (g) & $291.67^{\mathrm{d}}$ & $322.44^{c}$ & $349.26^{\mathrm{b}}$ & $359.79 \mathrm{ab}$ & $380.44^{\mathrm{a}}$ & $374.56^{\mathrm{a}}$ & 8.62 & $<0.0001$ & $<0.0001$ & $<0.0001$ \\
\hline Average daily gain $(\mathrm{g})$ & $12.28^{\mathrm{d}}$ & $13.74^{\mathrm{c}}$ & $15.02^{b}$ & $15.52 \mathrm{ab}$ & $16.50^{\mathrm{a}}$ & $16.22^{\mathrm{a}}$ & 0.41 & $<0.0001$ & $<0.0001$ & $<0.0001$ \\
\hline Average daily feed intake (g) & $24.13^{\mathrm{d}}$ & $25.77^{c}$ & $27.19^{b}$ & $28.70^{a}$ & $28.89^{\mathrm{a}}$ & $28.09 \mathrm{ab}$ & 0.47 & $<0.0001$ & $<0.0001$ & $<0.0001$ \\
\hline $\begin{array}{l}\text { Feed conversion ratio (g } \\
\text { feed: g weight) }\end{array}$ & $1.97^{\mathrm{a}}$ & $1.88^{\mathrm{b}}$ & $1.81^{b c}$ & $1.82^{b c}$ & $1.75^{\mathrm{c}}$ & $1.73^{c}$ & 0.003 & $<0.0001$ & $<0.0001$ & $<0.0001$ \\
\hline Variables & \multicolumn{2}{|c|}{ Model } & \multicolumn{3}{|c|}{ Regression Equation ${ }^{2}$} & $\begin{array}{l}\text { TotalDietary } \\
\text { Met Level (\%) }\end{array}$ & $\begin{array}{r}\text { To } \\
\text { Allo }\end{array}$ & $\begin{array}{l}\text { ily Met } \\
\text { e (g/day) }\end{array}$ & $S S R^{3}$ & $p$-Value \\
\hline \multirow{2}{*}{ Final body weight (g) } & \multicolumn{2}{|c|}{ Quadratic Polynomial } & \multicolumn{3}{|c|}{$Y=15.81+1340.52 X-1225.08 X^{2}$} & 0.55 & \multicolumn{2}{|c|}{0.149} & 12162.24 & $<0.0001$ \\
\hline & \multicolumn{2}{|c|}{ Exponential Asymptotic } & \multicolumn{3}{|c|}{$\begin{aligned} Y=291+ & 88.99 \times(1-\operatorname{EXP}(-11.42 \\
& \times(X-0.28)))\end{aligned}$} & 0.54 & \multicolumn{2}{|c|}{0.146} & 12218.97 & $<0.0001$ \\
\hline \multirow{2}{*}{ Average daily gain $(\mathrm{g})$} & \multicolumn{2}{|c|}{ Quadratic Polynomial } & \multicolumn{3}{|c|}{$Y=-0.86+63.83 X-58.34 X^{2}$} & 0.55 & \multicolumn{2}{|c|}{0.149} & 27.58 & $<0.0001$ \\
\hline & \multicolumn{2}{|c|}{ Exponential Asymptotic } & \multicolumn{3}{|c|}{$\begin{aligned} \mathrm{Y}=12.25 & +4.24 \times(1-\mathrm{EXP}(-11.42 \\
& \times(\mathrm{X}-0.28)))\end{aligned}$} & 0.54 & \multicolumn{2}{|c|}{0.146} & 27.71 & $<0.0001$ \\
\hline \multirow{2}{*}{ Average daily feed intake (g) } & \multicolumn{2}{|c|}{ Quadratic Polynomial } & \multicolumn{3}{|c|}{$Y=7.04+83.86 X-80.13 X^{2}$} & 0.52 & \multicolumn{2}{|c|}{0.141} & 28.29 & $<0.0001$ \\
\hline & \multicolumn{2}{|c|}{ Exponential Asymptotic } & \multicolumn{3}{|c|}{$\begin{aligned} \mathrm{Y}=24.03 & +4.58 \times(1-\mathrm{EXP}(-13.85 \\
& \times(\mathrm{X}-0.28)))\end{aligned}$} & 0.50 & \multicolumn{2}{|c|}{0.135} & 31.50 & $<0.0001$ \\
\hline Feed conversion ratio & & & \multicolumn{3}{|c|}{$Y=2.54-2.74 X+2.34 X^{2}$} & 0.58 & \multicolumn{2}{|c|}{0.157} & 0.212 & $<0.0001$ \\
\hline
\end{tabular}

In the same row, means not sharing a similar superscript $(\mathrm{a}, \mathrm{b}, \mathrm{c}, \mathrm{d})$ differ significantly $(p<0.05)$, the number of replicates was used as the experimental unit (n $=6) .{ }^{1}$ Standard error of the mean from ANOVA $(n=6) .{ }^{2}$ Where $Y$ is final body weight, average daily gain, average daily feed intake or feed conversion ratio and $\mathrm{X}$ is total dietary content of methionine. ${ }^{3}$ SSR $=$ sum of squared residuals.

Table 3. Effects of total dietary methionine level on growth performance of female Lingnan yellow-feathered chickens aged 1-21 days.

\begin{tabular}{|c|c|c|c|c|c|c|c|c|c|c|}
\hline \multirow{2}{*}{ Variables } & \multicolumn{6}{|c|}{ Total Dietary Methionine Levels (\%) } & \multirow{2}{*}{ SEM $^{1}$} & \multicolumn{3}{|c|}{$p$-Value } \\
\hline & 0.28 & 0.32 & 0.37 & 0.43 & 0.50 & 0.63 & & Met Level & Linear & Quadratic \\
\hline Final body weight (g) & $315.34^{c}$ & $332.84^{b}$ & $368.9^{a}$ & $377.26^{a}$ & $380.81^{a}$ & $370.91^{a}$ & 4.73 & $<0.0001$ & $<0.0001$ & $<0.0001$ \\
\hline Average daily gain $(\mathrm{g})$ & $13.17^{\mathrm{c}}$ & $14.00^{\mathrm{b}}$ & $15.72^{\mathrm{a}}$ & $16.12^{\mathrm{a}}$ & $16.29^{\mathrm{a}}$ & $15.82^{\mathrm{a}}$ & 0.23 & $<0.0001$ & $<0.0001$ & $<0.0001$ \\
\hline Average daily feed intake (g) & $28.53^{b}$ & $27.46^{\mathrm{c}}$ & $29.13^{a b}$ & $29.48^{a}$ & $27.69^{c}$ & $29.19 \mathrm{ab}$ & 0.15 & $<0.0001$ & 0.147 & 0.342 \\
\hline Feed conversion ratio (g:g) & $2.17^{\mathrm{a}}$ & $1.96^{\mathrm{b}}$ & $1.852^{b c}$ & $1.83^{\mathrm{c}}$ & $1.70^{\mathrm{d}}$ & $1.85^{b c}$ & 0.029 & $<0.0001$ & $<0.0001$ & $<0.0001$ \\
\hline
\end{tabular}


Table 3. Cont.

\begin{tabular}{|c|c|c|c|c|c|c|}
\hline Variables & Model & Regression Equation $^{2}$ & $\begin{array}{c}\text { Total Dietary Met } \\
\text { Level, } \%\end{array}$ & $\begin{array}{l}\text { TotalDaily Met Fed } \\
\text { Allowance, g/day }\end{array}$ & $S S R^{3}$ & $p$-Value \\
\hline \multirow{2}{*}{ Final body weight (g) } & $\begin{array}{l}\text { Quadratic } \\
\text { Polynomial }\end{array}$ & $Y=46.14+1323.09 X-1285.88 X^{2}$ & 0.51 & 0.145 & 7316.66 & $<0.0001$ \\
\hline & $\begin{array}{l}\text { Exponential } \\
\text { Asymptotic }\end{array}$ & $\begin{aligned} Y=311.9 & +67.2 \times(1-\mathrm{EXP}(-15.64 \\
& \times(X-0.28)))\end{aligned}$ & 0.47 & 0.134 & 7992.86 & $<0.0001$ \\
\hline Average daily gain (g) & $\begin{array}{l}\text { Quadratic } \\
\text { Polynomial }\end{array}$ & $Y=0.35+63.00 X-61.23 X^{2}$ & 0.51 & 0.145 & 16.59 & $<0.0001$ \\
\hline \multirow{2}{*}{ Feed conversion ratio } & $\begin{array}{l}\text { Exponential } \\
\text { Asymptotic }\end{array}$ & $\begin{aligned} Y=13.01 & +3.20 \times(1-\mathrm{EXP}(-15.64 \\
& \times(X-0.28)))\end{aligned}$ & 0.47 & 0.134 & 18.12 & $<0.0001$ \\
\hline & $\begin{array}{l}\text { Quadratic } \\
\text { Polynomial }\end{array}$ & $Y=3.86-8.47 X+8.38 X^{2}$ & 0.51 & 0.145 & 0.281 & $<0.0001$ \\
\hline
\end{tabular}

In the same row, means not sharing a similar superscript (a, b, c, d) differ significantly $(p<0.05)$, the number of replicates was used as the experimental unit $(\mathrm{n}=6) .{ }^{1}$ Standard error of the mean from ANOVA $(n=6) .{ }^{2}$ Where $Y$ is final body weight, average daily gain, or feed conversion ratio and $\mathrm{X}$ is total dietary content of methionine. ${ }^{3} \mathrm{SSR}=$ sum of squared residuals.

Table 4. Effects of total dietary methionine level on growth performance of mixed male and female Lingnan yellow-feathered chickens aged 1-21 days.

\begin{tabular}{|c|c|c|c|c|c|c|c|c|c|c|}
\hline \multirow{2}{*}{ Variables } & \multicolumn{6}{|c|}{ Total Dietary Methionine Levels (\%) } & \multirow{2}{*}{ SEM $^{1}$} & \multicolumn{3}{|c|}{$p$-Value } \\
\hline & 0.28 & 0.32 & 0.37 & 0.43 & 0.50 & 0.63 & & Met level & Linear & Quadratic \\
\hline Final body weight (g) & $303.50^{d}$ & $327.65^{c}$ & $359.10^{\mathrm{b}}$ & $368.53^{a b}$ & $380.62^{a}$ & $372.73^{a b}$ & 3.87 & $<0.0001$ & $<0.0001$ & $<0.0001$ \\
\hline Average daily gain $(\mathrm{g})$ & $12.72^{\mathrm{d}}$ & $13.87^{\mathrm{c}}$ & $15.37^{\mathrm{b}}$ & $15.82^{a b}$ & $16.40^{\mathrm{a}}$ & $16.02^{a b}$ & 0.18 & $<0.0001$ & $<0.0001$ & $<0.0001$ \\
\hline Average daily feed intake $(\mathrm{g})$ & $26.33^{b}$ & $26.62^{b}$ & $28.16^{\mathrm{a}}$ & $28.72^{\mathrm{a}}$ & $28.29^{a}$ & $28.64^{\mathrm{a}}$ & 0.19 & $<0.0001$ & $<0.0001$ & $<0.0001$ \\
\hline Feed conversion ratio (g:g) & $2.07^{\mathrm{a}}$ & $1.92^{\mathrm{b}}$ & $1.83^{c}$ & $1.82^{\mathrm{c}}$ & $1.73^{\mathrm{d}}$ & $1.79^{\mathrm{cd}}$ & 0.017 & $<0.0001$ & 0.123 & 0.108 \\
\hline Variables & \multicolumn{2}{|c|}{ Model } & \multicolumn{3}{|c|}{ Regression Equation $^{2}$} & \multicolumn{2}{|c|}{$\begin{array}{l}\text { Total Dietary Met } \\
\text { Level, \% }\end{array}$} & $\begin{array}{l}\text { Total Daily Met Fed } \\
\text { Allowance, g/day }\end{array}$ & $S S R^{3}$ & $p$-Value \\
\hline \multirow{2}{*}{ Final body weight (g) } & \multicolumn{2}{|c|}{ Quadratic Polynomial } & \multicolumn{3}{|c|}{$Y=30.97+1331.80 X-1255.48 X^{2}$} & \multicolumn{2}{|c|}{0.53} & 0.147 & 4164.46 & $<0.0001$ \\
\hline & \multicolumn{2}{|c|}{ Exponential Asymptotic } & \multicolumn{3}{|c|}{$\begin{aligned} Y=301.3+ & 77.56 \times(1-\operatorname{EXP}(-13.46 \\
& \times(X-0.28)))\end{aligned}$} & \multicolumn{2}{|c|}{0.50} & 0.139 & 4413.55 & $<0.0001$ \\
\hline \multirow{2}{*}{ Average daily gain (g) } & \multicolumn{2}{|c|}{ Quadratic Polynomial } & \multicolumn{3}{|c|}{$Y=-0.25+63.42 X-59.79 X^{2}$} & \multicolumn{2}{|c|}{0.53} & 0.147 & 9.443 & $<0.0001$ \\
\hline & \multicolumn{2}{|c|}{ Exponential Asymptotic } & \multicolumn{3}{|c|}{$\begin{array}{c}\mathrm{Y}=12.62+3.69 \times(1-\mathrm{EXP}(-13.46 \\
\times(X-0.28)))\end{array}$} & \multicolumn{2}{|c|}{0.50} & 0.139 & 10.008 & $<0.0001$ \\
\hline
\end{tabular}


Table 4. Cont.

\begin{tabular}{|c|c|c|c|c|c|c|}
\hline \multirow{2}{*}{ Average daily feed intake (g) } & Quadratic Polynomial & $Y=17.71+41.35 X-38.39 X^{2}$ & 0.53 & 0.147 & 14.597 & $<0.0001$ \\
\hline & Exponential Asymptotic & $\begin{aligned} \mathrm{Y}=26.14 & +2.59 \times(1-\mathrm{EXP}(-12.47 \\
& \times(\mathrm{X}-0.28)))\end{aligned}$ & 0.52 & 0.145 & 14.958 & $<0.0001$ \\
\hline
\end{tabular}

In the same row, means not sharing a similar superscript $(\mathrm{a}, \mathrm{b}, \mathrm{c}, \mathrm{d})$ differ significantly $(p<0.05)$, the number of replicates was used as the experimental unit $(\mathrm{n}=6) .{ }^{1}$ Standard error of the mean from ANOVA $(n=6) .{ }^{2}$ Where $Y$ is final body weight, average daily gain or average daily feed intake and $\mathrm{X}$ is total dietary content of methionine. ${ }^{3}$ SSR $=$ sum of squared residuals. 

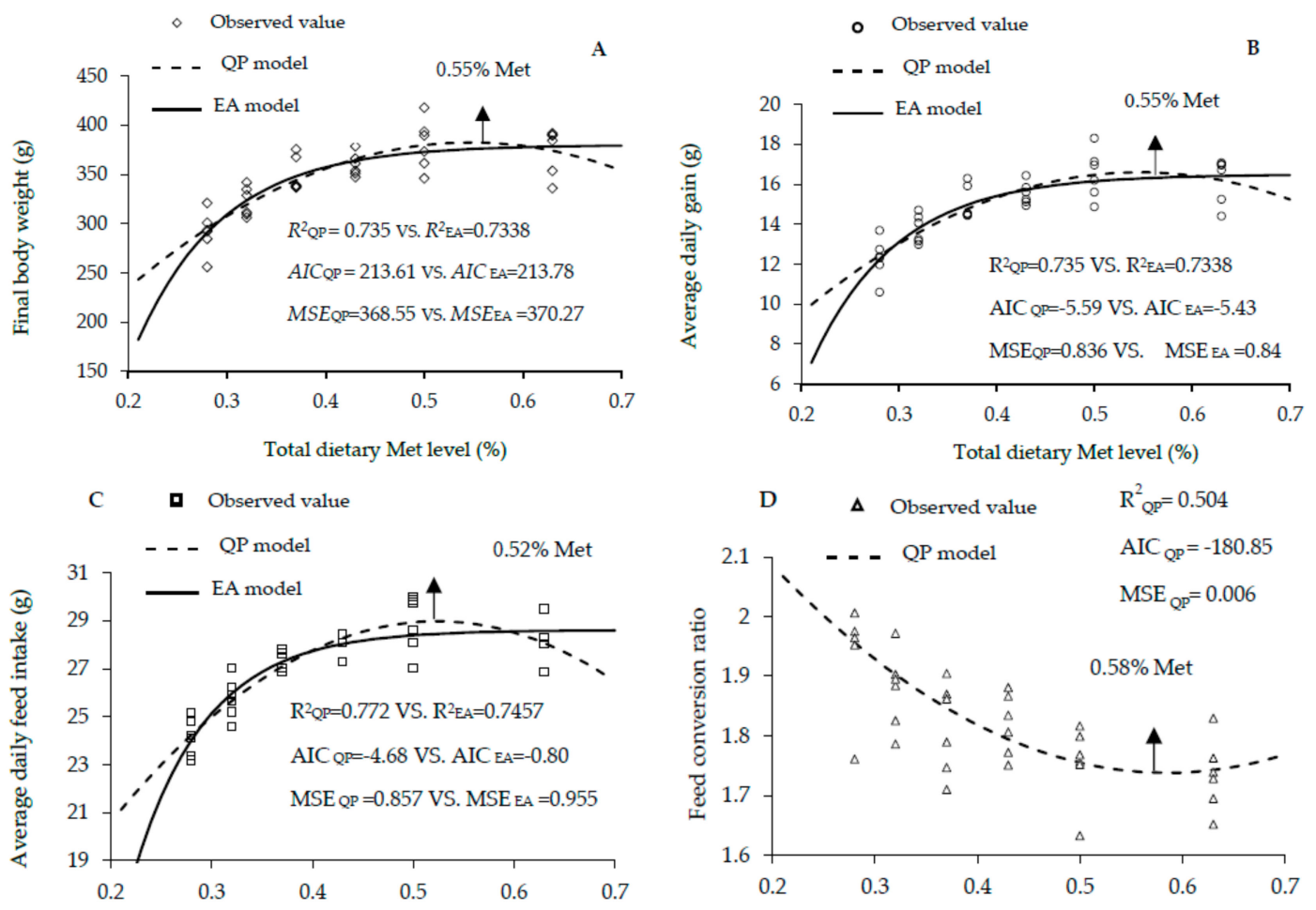

Total dietary Met level (\%)

Total dietary Met level (\%)

Figure 1. Regression models plot of growth performance as a function of total dietary Met level (0.28, $0.32 \%, 0.37 \%, 0.43 \%, 0.50 \%$, and $0.63 \%$ Met ) of male rapidly growing yellow-feathered chickens between 0 and 21 days of age. Correlation coefficient $\left(R^{2}\right)$, Akaike information criteria (AIC), and mean squares error (MSE) are indicators for evaluating model fitness. (A) The optimum response arrow pointing at $0.55 \%$ Met by quadratic polynomial (QP) model. (B) The optimum response arrow pointing at $0.55 \%$ Met by QP model. (C) The optimum response arrow pointing at $0.52 \%$ Met by QP model. (D) The optimum response arrow pointing at $0.58 \%$ Met according to the QP model.
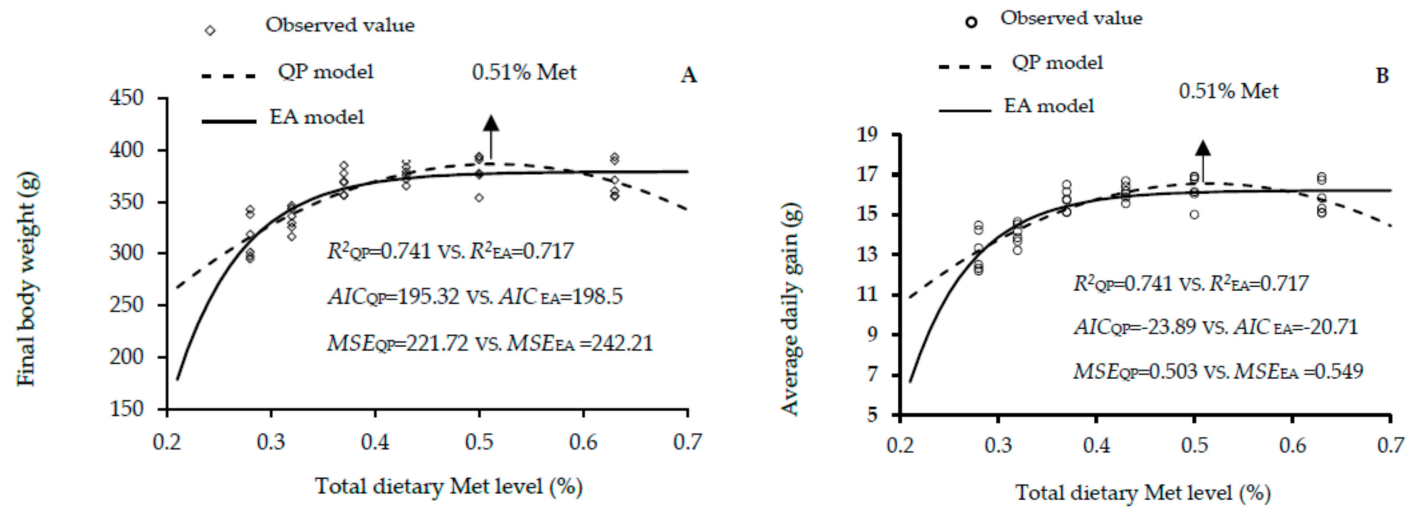

Figure 2. Cont. 


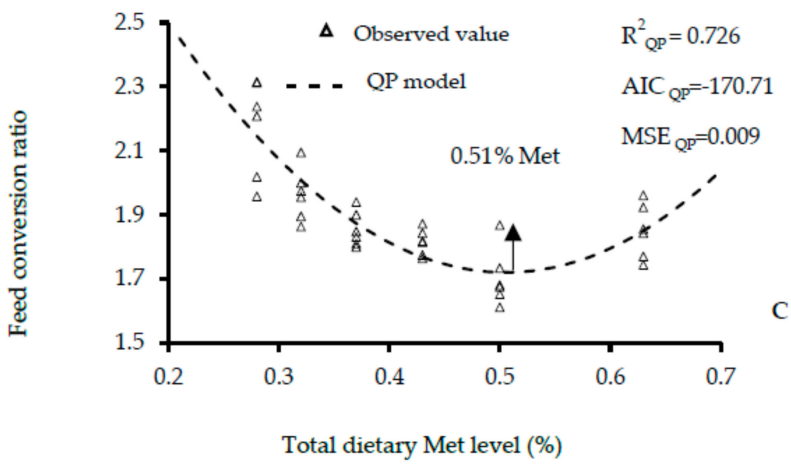

Figure 2. Regression models plot of growth performance as a function of total dietary Met level $(0.28 \%$, $0.32 \%, 0.37 \%, 0.43 \%, 0.50 \%$, and $0.63 \%$ Met) of female rapidly growing yellow-feathered chickens between 0 and 21 days of age. Correlation coefficient $\left(R^{2}\right)$, Akaike information criteria (AIC), and mean squares error (MSE) are indicators used in evaluating fitness of models. (A) The optimum response arrow pointing at $0.51 \%$ Met by the best fitting regression model. (B) The optimum response arrow pointing at $0.51 \%$ Met identified by the best fitting model. (C) The optimum response arrow pointing at $0.51 \%$ Met.

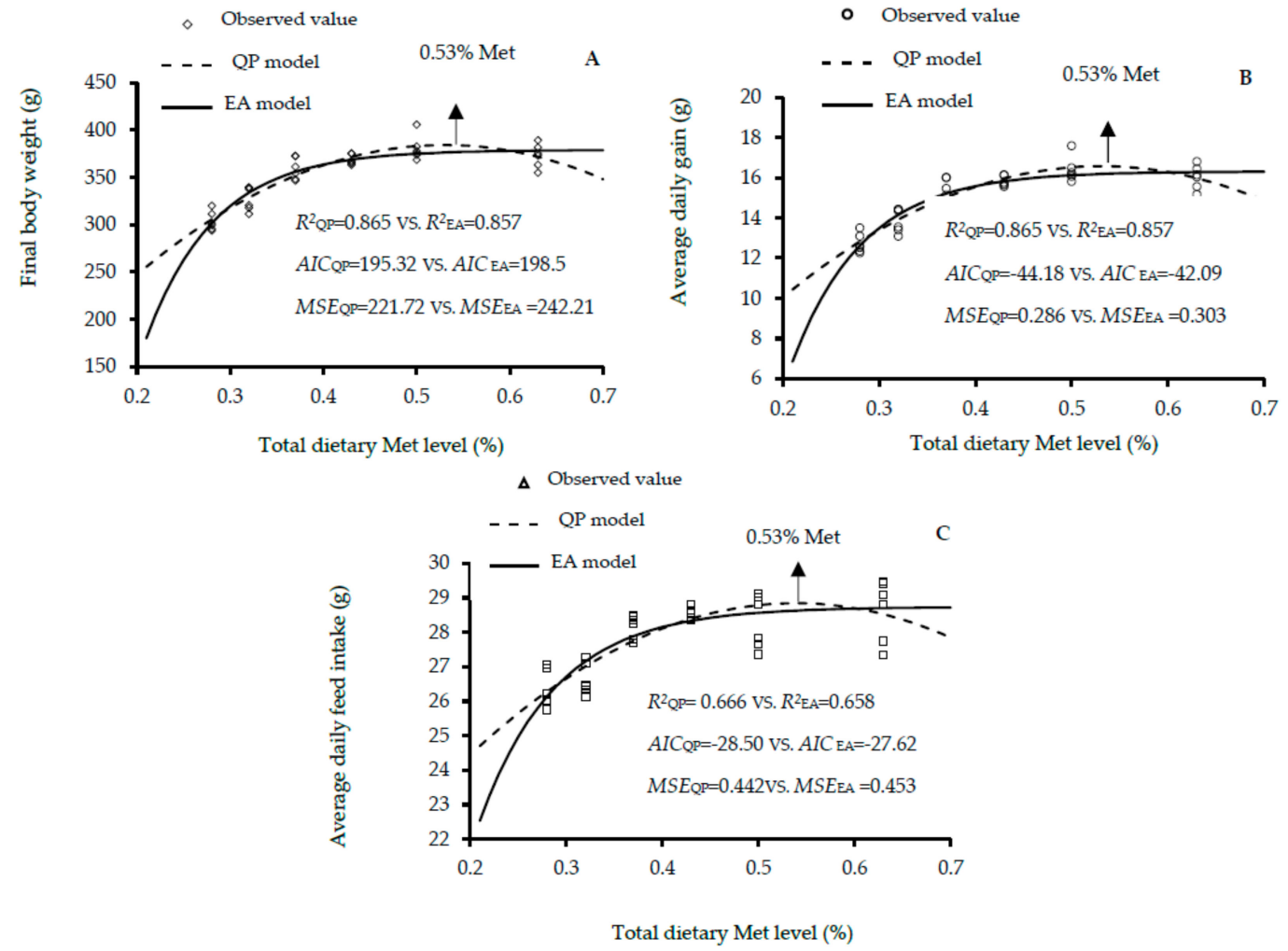

Figure 3. Regression models plot of growth performance as a function of total dietary Met level (0.28\%, $0.32 \%, 0.37 \%, 0.43 \%, 0.50 \%$, and $0.63 \%$ Met) of mixed sex rapidly growing yellow-feathered chickens aged 0 and 21 days of age. Correlation coefficient $\left(R^{2}\right)$, Akaike information criteria (AIC) and mean squares error (MSE) are used as indicators for evaluation model fitness. (A) The optimum response arrow pointing at $0.53 \%$ Met according to QP model. (B) The optimum response arrow pointing at $0.53 \%$ Met by QP model. (C) The optimum response arrow pointing at $0.53 \%$ Met.

\subsection{Growth Performance of Guangxi Broilers Aged from 1 to 30 Days (Exp 2)}

The growth performance results of male, female and mixed genders of Guangxi yellow-feathered chickens as affected by dietary Met levels between 1 and 30 days of age are shown in Tables 5-7. The increase in dietary Met level showed linear and quadratic effects on the final BW (linear and quadratic, 
$p<0.01$ ), ADG (linear and quadratic, $p<0.01$ ) and ADFI (linear, $p<0.01$; quadratic, $p<0.05$ ) of males; final BW, ADG, and ADG (linear, $p<0.01$; quadratic, $p<0.01$ ) of females; and final BW (linear, $p<0.01$; quadratic, $p<0.01$ ), ADG (linear, $p<0.01$; quadratic, $p<0.01$ ), and ADFI (linear and quadratic, $p<0.05$ ) of mixed genders. According to the EA and QP regression models, the optimal Met for the highest final BW were $0.51 \%$ and 0.53 in males, $0.43 \%$ and $0.51 \%$ in females, and $0.48 \%$ and $0.52 \%$ in the mixed males and females. The EA and QP indicated that the optimal Met for the maximal ADG were 0.51 and $0.53 \%$ in males, $0.43 \%$ and $0.51 \%$ in females, and $0.48 \%$ and $0.52 \%$ in mixed genders. Additionally, the QP model showed that $0.49 \%$ was optimal for the best FCR in mixed genders. Fitness of the two growth performance models are shown in Figures 4-6. QP models showed higher $\mathrm{R}^{2}$, lower AIC and MSE values, in estimating the optimal Met requirement (Figure $4 a, b$ and Figure $6 a, b$ ) for growth performance of males, whereas the EA model in females and mixed sexes, had higher $\mathrm{R}^{2}$, and the lower AIC and MSE values. These results reveal that the QP model are more fitting to predict Met requirement for growing Guangxi males (0-30 days), but the EA function was better fitting for females and mixed sexes. The QP models predicted the requirement of Met for males as $0.53 \%$, and the EA models predicted the requirements of Met for females and mixed genders as $0.43 \%$ and $0.48 \%$ to $0.49 \%$, respectively.
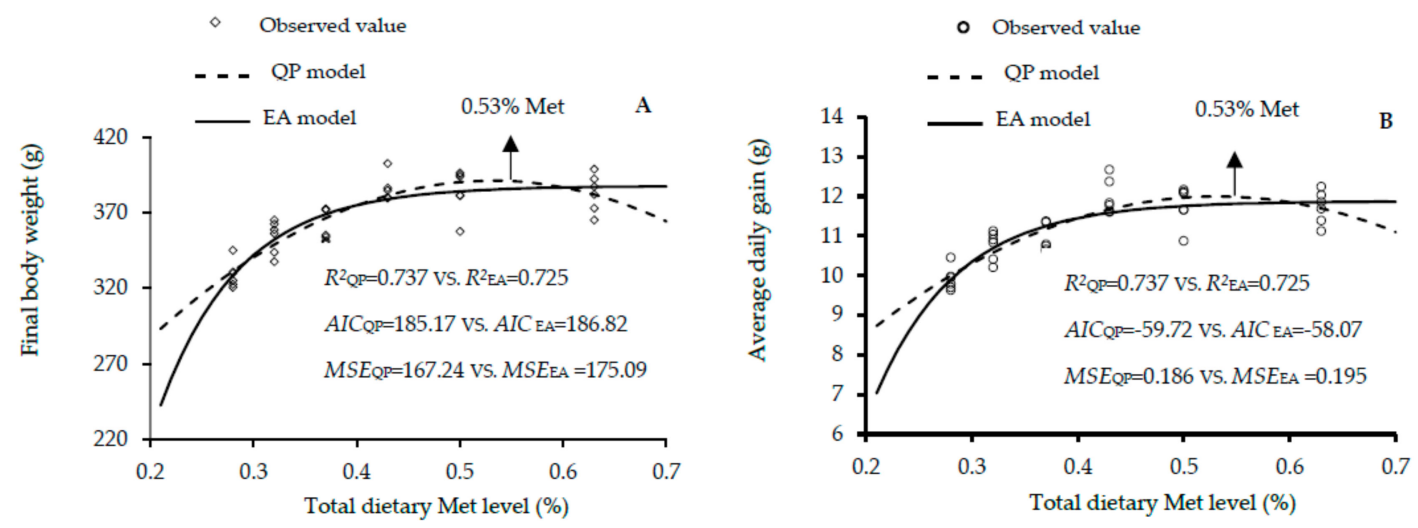

Figure 4. Regression models plot of growth performance as a function of total dietary Met level $(0.28 \%$, $0.32 \%, 0.37 \%, 0.43 \%, 0.50 \%$, and $0.63 \%$ Met) of male slowly growing yellow-feathered chickens between 0 and 30 days of age. Correlation coefficient $\left(R^{2}\right)$, Akaike information criteria (AIC) and mean squares error (MSE) are indicators used to evaluate fitness of models. (A) The optimum response arrow pointing at $0.53 \%$ Met by the best fitting model. (B) The optimum response arrow pointing at $0.53 \%$ Met by the best fitting regression model. 
Table 5. Effects of total dietary methionine level on growth performance of male Guangxi yellow-feathered chickens aged 1 to 30 days.

\begin{tabular}{|c|c|c|c|c|c|c|c|c|c|c|}
\hline \multirow{2}{*}{ Variables } & \multicolumn{6}{|c|}{ Total Dietary Methionine Levels (\%) } & \multirow{2}{*}{ SEM $^{1}$} & \multicolumn{3}{|c|}{$p$-Value } \\
\hline & 0.28 & 0.32 & 0.37 & 0.43 & 0.50 & 0.63 & & Met Level & Linear & Quadratic \\
\hline Final body weight (g) & $328.96^{c}$ & $353.96^{b}$ & $359.07^{b}$ & $390.74^{\mathrm{a}}$ & $384.15^{\mathrm{a}}$ & $383.04^{\mathrm{a}}$ & 6.18 & $<0.0001$ & $<0.0001$ & $<0.0001$ \\
\hline Average daily gain $(\mathrm{g})$ & $9.92^{\mathrm{c}}$ & $10.75^{\mathrm{b}}$ & $10.92^{b}$ & $11.97^{\mathrm{a}}$ & $11.75^{\mathrm{a}}$ & $11.70^{\mathrm{a}}$ & 0.21 & $<0.0001$ & $<0.0001$ & $<0.0001$ \\
\hline Average daily feed intake (g) & $25.76^{\mathrm{b}}$ & $25.82^{b}$ & $26.37^{a b}$ & $28.21^{\mathrm{ab}}$ & $27.29^{a b}$ & $28.84^{\mathrm{a}}$ & 0.82 & 0.0035 & 0.003 & 0.114 \\
\hline Feed conversion ratio $(\mathrm{g}: \mathrm{g})$ & 2.6 & 2.41 & 2.41 & 2.35 & 2.32 & 2.46 & 0.08 & 0.1508 & & \\
\hline Variables & \multicolumn{2}{|c|}{ Model } & \multicolumn{3}{|c|}{ Regression Equation $^{2}$} & \multicolumn{2}{|c|}{$\begin{array}{l}\text { Total Dietary Met } \\
\text { Level (\%) }\end{array}$} & $\begin{array}{l}\text { Total Daily Met fed } \\
\text { Allowance (g/day) }\end{array}$ & $S S R^{3}$ & $p$-Value \\
\hline \multirow{2}{*}{ Final body weight (g) } & \multicolumn{2}{|c|}{$\begin{array}{c}\text { Quadratic } \\
\text { Polynomial }\end{array}$} & \multicolumn{3}{|c|}{$Y=123.45+1007.30 X-947.59 X^{2}$} & \multicolumn{2}{|c|}{0.53} & 0.143 & 5518.908 & $<0.0001$ \\
\hline & \multicolumn{2}{|c|}{$\begin{array}{l}\text { Exponential } \\
\text { Asymptotic }\end{array}$} & \multicolumn{3}{|c|}{$\begin{array}{l}Y=328.50+59.13 \times(1- \\
\operatorname{EXP}(-12.83 \times(X-0.28)))\end{array}$} & \multicolumn{2}{|c|}{0.51} & 0.138 & 5777.969 & $<0.0001$ \\
\hline \multirow{2}{*}{ Average daily gain (g) } & \multicolumn{2}{|c|}{$\begin{array}{l}\text { Quadratic } \\
\text { Polynomial }\end{array}$} & \multicolumn{3}{|c|}{$Y=3.07+33.58 X-31.59 X^{2}$} & \multicolumn{2}{|c|}{0.53} & 0.143 & 6.132 & $<0.0001$ \\
\hline & \multicolumn{2}{|c|}{$\begin{array}{l}\text { Exponential } \\
\text { Asymptotic }\end{array}$} & \multicolumn{3}{|c|}{$\begin{array}{c}\mathrm{Y}=9.90+1.97 \times(1-\operatorname{EXP}(-12.83 \times \\
(\mathrm{X}-0.28)))\end{array}$} & \multicolumn{2}{|c|}{0.51} & 0.138 & 6.42 & $<0.0001$ \\
\hline
\end{tabular}

In the same row, means not sharing a similar superscript $(\mathrm{a}, \mathrm{b}, \mathrm{c})$ differ significantly $(p<0.05)$, the number of replicates was used as the experimental unit $(\mathrm{n}=6) .{ }^{1}$ Standard error of the mean from ANOVA $(n=6) .{ }^{2}$ Where $\mathrm{Y}$ is final body weight or average daily gain and $\mathrm{X}$ is total dietary content of methionine. ${ }^{3} \mathrm{SSR}=$ sum of squared residuals.

Table 6. Effects of total dietary methionine level on growth performance of female Guangxi yellow-feathered chickens aged 1 to 30 days.

\begin{tabular}{|c|c|c|c|c|c|c|c|c|c|c|}
\hline \multirow{2}{*}{ Variables } & \multicolumn{6}{|c|}{ Total Dietary Methionine levels (\%) } & \multirow{2}{*}{ SEM $^{1}$} & \multicolumn{3}{|c|}{$p$-Value } \\
\hline & 0.28 & 0.32 & 0.37 & 0.43 & 0.50 & 0.63 & & Met Level & Linear & Quadratic \\
\hline Final body weight (g) & $308.50^{c}$ & $318.82 \mathrm{bc}$ & $329.90^{a b}$ & $340.57^{a}$ & $327.14^{\mathrm{ab}}$ & $332.34^{\mathrm{ab}}$ & 5.61 & 0.0023 & 0.011 & 0.001 \\
\hline Average daily gain $(\mathrm{g})$ & $9.25^{c}$ & $9.59 \mathrm{bc}$ & $9.96^{\mathrm{ab}}$ & $10.31^{\mathrm{a}}$ & $9.87^{\mathrm{ab}}$ & $10.04^{\mathrm{ab}}$ & 0.19 & 0.0023 & 0.011 & 0.001 \\
\hline Average daily feed intake (g) & 25.57 & 26.82 & 24.96 & 26.31 & 25.58 & 24.62 & 1.11 & 0.45 & & \\
\hline Feed conversion ratio (g:g) & 2.77 & 2.79 & 2.51 & 2.55 & 2.59 & 2.45 & 0.11 & 0.21 & & \\
\hline
\end{tabular}


Table 6. Cont.

\begin{tabular}{|c|c|c|c|c|c|c|}
\hline Variables & Model & Regression Equation ${ }^{2}$ & $\begin{array}{l}\text { Total Dietary } \\
\text { Met Level, \% }\end{array}$ & $\begin{array}{l}\text { Total Daily Met Fed } \\
\text { Allowance, g/day }\end{array}$ & $S S R^{3}$ & $p$-Value \\
\hline \multirow{2}{*}{ Final body weight (g) } & Quadratic Polynomial & $Y=210.40+493.91 X-482.58 X^{2}$ & 0.51 & 0.131 & 5682.55 & 0.001 \\
\hline & Exponential Asymptotic & $\begin{aligned} Y=307.6 & +25.8 \times(1-\mathrm{EXP}(-20.29 \\
& \times(\mathrm{X}-0.28)))\end{aligned}$ & 0.43 & 0.110 & 5432.792 & 0.0006 \\
\hline \multirow{2}{*}{ Average daily gain (g) } & Quadratic Polynomial & $Y=5.98+16.46 X-16.09 X^{2}$ & 0.51 & 0.131 & 6.314 & 0.001 \\
\hline & Exponential Asymptotic & $\begin{array}{c}\mathrm{Y}=9.22+0.86 \times(1-\operatorname{EXP}(-20.29 \times \\
(\mathrm{X}-0.28)))\end{array}$ & 0.43 & 0.110 & 6.036 & 0.0006 \\
\hline
\end{tabular}

In the same row, means not sharing a similar superscript $(\mathrm{a}, \mathrm{b}, \mathrm{c})$ differ significantly $(p<0.05)$, the number of replicates was used as the experimental unit $(\mathrm{n}=6) .{ }^{1}$ Standard error of the mean from ANOVA $(n=6) .{ }^{2}$ Where $\mathrm{Y}$ is final body weight or average daily gain and $\mathrm{X}$ is total dietary content of methionine. ${ }^{3} \mathrm{SSR}=$ sum of squared residuals.

Table 7. Effects of total dietary methionine level on growth performance of mixed male and female Guangxi yellow-feathered chickens aged 1 to 30 days.

\begin{tabular}{|c|c|c|c|c|c|c|c|c|c|c|}
\hline \multirow{2}{*}{ Variables } & \multicolumn{6}{|c|}{ Total Dietary Methionine Levels (\%) } & \multirow{2}{*}{ SEM $^{1}$} & \multicolumn{3}{|c|}{$p$-Value } \\
\hline & 0.28 & 0.32 & 0.37 & 0.43 & 0.50 & 0.63 & & Met Level & Linear & Quadratic \\
\hline Final body weight (g) & $318.73^{c}$ & $336.39 \mathrm{bc}$ & $344.49^{a b}$ & $365.66^{a}$ & $355.64^{a b}$ & $357.69^{a b}$ & 4.28 & $<0.0001$ & $<0.0001$ & $<0.0001$ \\
\hline Average daily gain $(\mathrm{g})$ & $9.58^{c}$ & $10.17^{b c}$ & $10.44^{\mathrm{ab}}$ & $11.15^{\mathrm{a}}$ & $10.81^{\mathrm{ab}}$ & $10.88^{\mathrm{ab}}$ & 0.14 & $<0.0001$ & $<0.0001$ & $<0.0001$ \\
\hline Average daily feed intake (g) & 25.67 & 26.32 & 25.67 & 27.26 & 26.44 & 26.73 & 0.43 & 0.2473 & & \\
\hline Feed conversion ratio (g:g) & $2.68^{\mathrm{a}}$ & $2.60^{\mathrm{ab}}$ & $2.46^{\mathrm{b}}$ & $2.45^{\mathrm{b}}$ & $2.45^{b}$ & $2.46^{\mathrm{b}}$ & 0.041 & 0.0105 & 0.027 & 0.016 \\
\hline Variables & \multicolumn{2}{|c|}{ Model } & \multicolumn{3}{|c|}{ Regression Equation ${ }^{2}$} & $\begin{array}{l}\text { Total Dietary } \\
\text { Met Level, \% }\end{array}$ & \multicolumn{2}{|c|}{$\begin{array}{l}\text { Total Daily Met Fed } \\
\text { Allowance, g/day }\end{array}$} & $S S R^{3}$ & $p$-Value \\
\hline \multirow{2}{*}{ Final body weight (g) } & \multicolumn{2}{|c|}{ Quadratic Polynomial } & \multicolumn{3}{|c|}{$Y=166.93+750.60 X-715.09 X^{2}$} & 0.52 & \multicolumn{2}{|c|}{0.137} & 3466.707 & $<0.0001$ \\
\hline & \multicolumn{2}{|c|}{ Exponential Asymptotic } & \multicolumn{3}{|c|}{$\begin{aligned} Y=318.0+ & 42.06 \times(1-\operatorname{EXP}(-15.14 \\
& \times(X-0.28)))\end{aligned}$} & 0.48 & \multicolumn{2}{|c|}{0.126} & 3396.603 & $<0.0001$ \\
\hline \multirow{2}{*}{ Average daily gain $(\mathrm{g})$} & \multicolumn{2}{|c|}{ Quadratic Polynomial } & \multicolumn{3}{|c|}{$Y=4.52+25.02 X-23.84 X^{2}$} & 0.52 & \multicolumn{2}{|c|}{0.137} & 3.852 & $<0.0001$ \\
\hline & \multicolumn{2}{|c|}{ Exponential Asymptotic } & \multicolumn{3}{|c|}{$\begin{array}{c}Y=9.56+1.40 \times(1-\operatorname{EXP}(-15.14 \times \\
(X-0.28)))\end{array}$} & 0.48 & \multicolumn{2}{|c|}{0.126} & 3.774 & $<0.0001$ \\
\hline Feed conversion ratio & \multicolumn{2}{|c|}{ Quadratic Polynomial } & \multicolumn{3}{|c|}{$\mathrm{Y}=3.60-4.58 \mathrm{X}+4.41 \mathrm{X}^{2}$} & 0.49 & \multicolumn{2}{|c|}{0.129} & 0.874 & 0.016 \\
\hline
\end{tabular}

In the same row, means not sharing a similar superscript $(\mathrm{a}, \mathrm{b}, \mathrm{c})$ differ significantly $(p<0.05)$, the number of replicates was used as the experimental unit $(\mathrm{n}=6)$. ${ }^{1}$ Standard error of the mean from ANOVA $(n=6) .{ }^{2}$ Where $Y$ is final body weight, average daily gain or feed conversion ratio and $\mathrm{X}$ is total dietary content of methionine. ${ }^{3}$ SSR $=$ sum of squared residuals. 

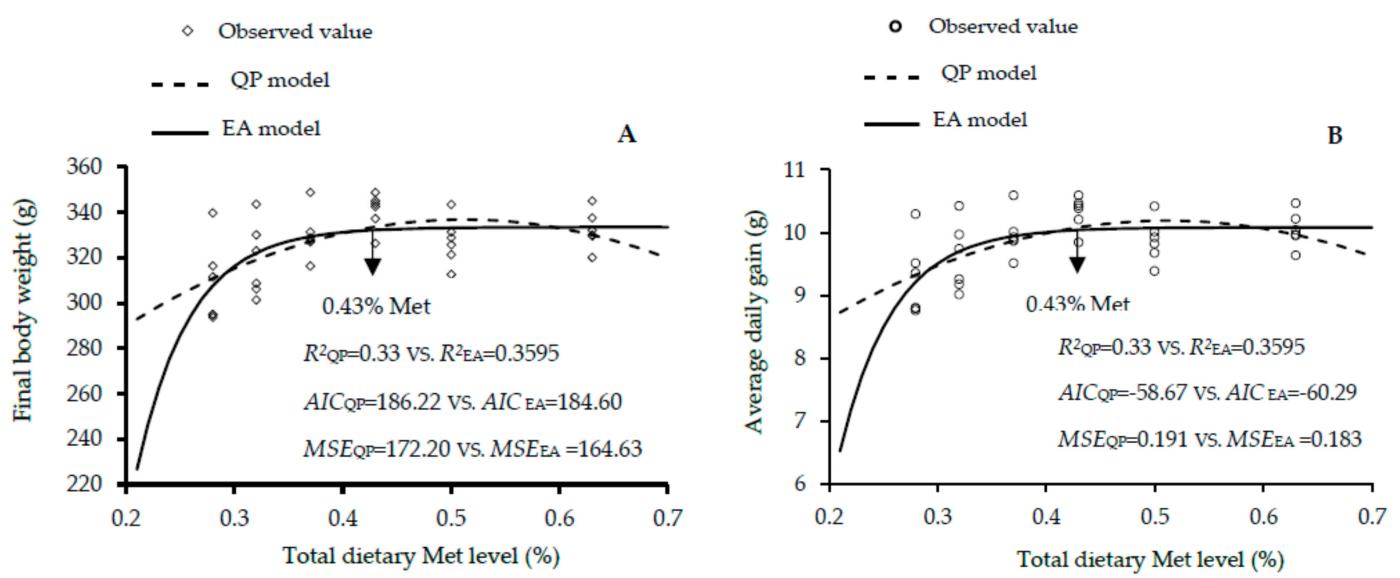

Figure 5. Regression models plot of growth performance as a function of total dietary Met level $(0.28 \%$, $0.32 \%, 0.37 \%, 0.43 \%, 0.50 \%$, and $0.63 \%$ Met) of female slowly growing yellow-feathered chickens between 0 and 30 days of age. Correlation coefficient $\left(R^{2}\right)$, Akaike information criteria (AIC) and mean squares error (MSE) are indicators used in evaluating fitness of models. (A) The optimum response arrow pointing at $0.43 \%$ Met by the best fitting model. (B) The optimum response arrow pointing at $0.43 \%$ Met identified by the best fitting regression model.
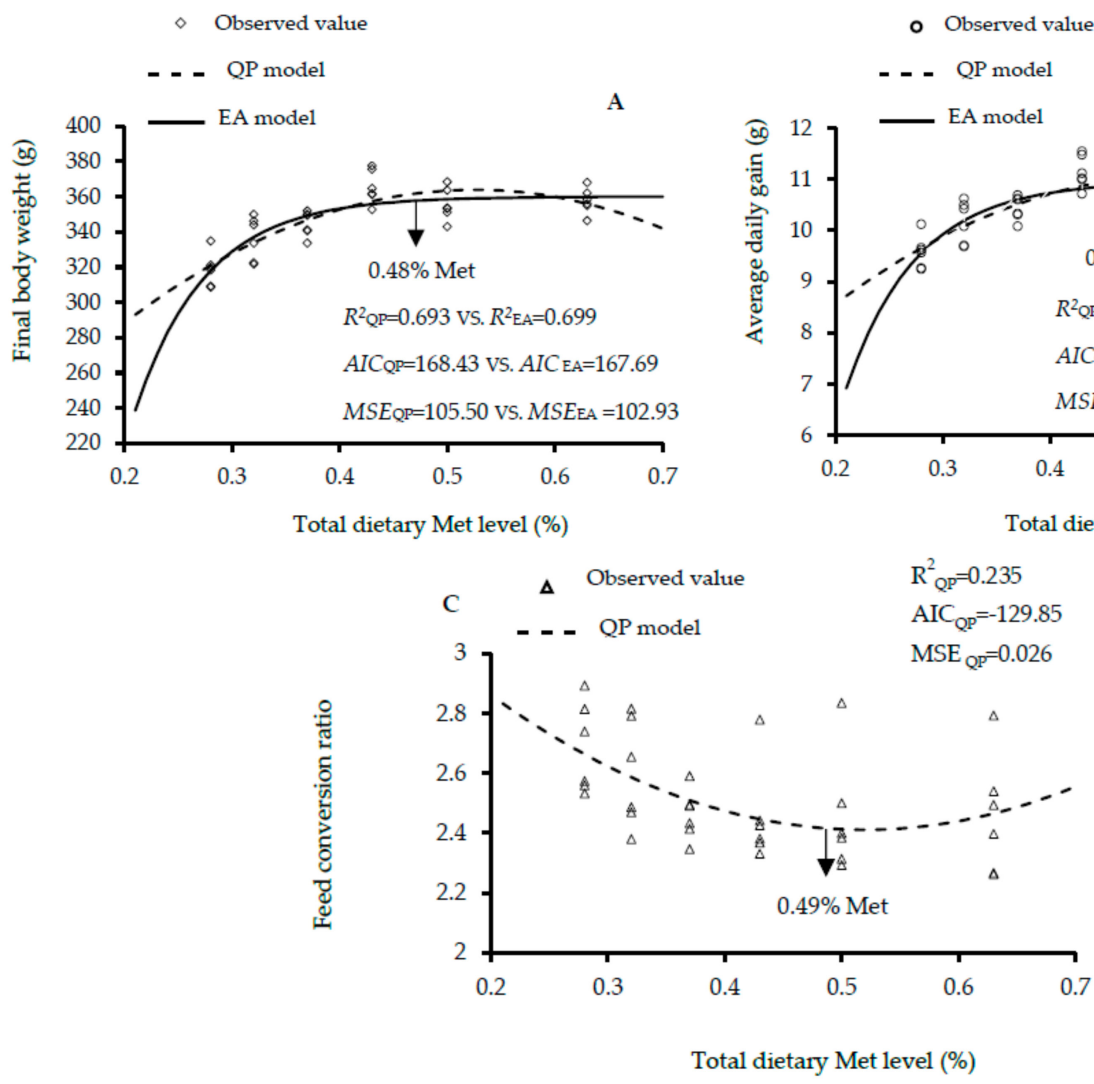

Total dietary Met level (\%)
- Observed value

- - QP model

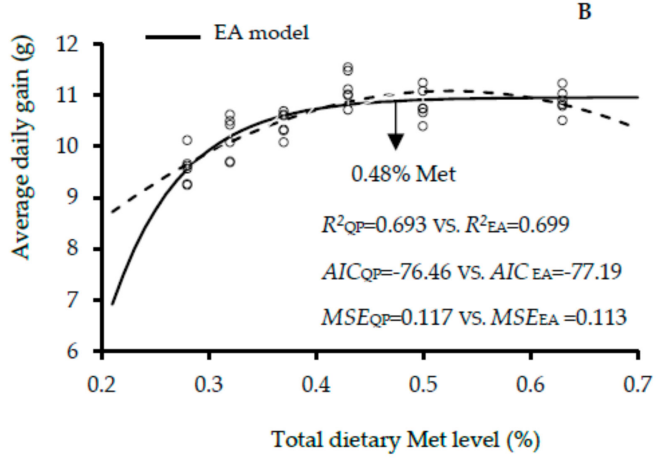

$\mathrm{R}_{\mathrm{QP}}^{2}=0.235$

$\mathrm{AIC}_{\mathrm{QP}}=-129.85$

Figure 6. Regression models plot of growth performance as a function of dietary total Met level $(0.28 \%$, $0.32 \%, 0.37 \%, 0.43 \%, 0.50 \%$, and $0.63 \%$ Met ) of mixed sexes of slowly growing yellow-feathered chickens between 0 and 30 days of age. Correlation coefficient $\left(R^{2}\right)$, Akaike information criteria (AIC) and mean squares error (MSE) are indicators of models fitness. (A) The optimum response arrow pointing at $0.48 \%$ Met by the best fitting model. (B) The optimum response arrow pointing at $0.48 \%$ Met identified by the best fitting model. (C) The optimum response arrow pointing at $0.49 \%$ Met. 


\section{Discussion}

Diets having low or excessive Met levels could engender important influences on poultry performance [21]. An optimal dietary Met concentration could significantly improve growth performance of broiler chickens when the Met level was lower in the diet [4,5,22-24]. The results of the present study confirm that increasing the dietary Met level improved growth performance of Liangnan and Guangxi chicks. This improvement in growth performance is attributable to the important roles of Met in animal's body, as mentioned in the introduction. Tsiagbe et al. [25] demonstrated that the Met has direct influences on growth performance and immunity in meat-type chickens. In a like manner, Carew et al. [26] reported that Met deficiency reduces the growth and development of lymphoid organs, which have negative effects on growth. The excess of Met, higher than the requirement, is used to cover requirement of some important amino acids such as cystine; two molecules of Met are used in synthesizing one molecule of cystine [27], whereas Met requirement can be covered only by dietary methionine. Additionally, the results here indicated that an excess of dietary Met level did not synchronously improve growth performance of birds and even showed a tendency of negative effects, which was consistent with the findings of Jamroz et al. [28]. Excessive levels of dietary Met can have negative effects on growth. The results of D'Mello and D'Mello [29] indicated that the dietary addition of 20 or $40 \mathrm{~g} / \mathrm{kg}$ of excess methionine decreased feed intake and reduced body weight gain. Edmonds and Baker [30] found that using an excess of Met at $4 \%$ of a corn-soybean meal diet containing $23 \%$ protein reduced body weight gain by $92 \%$, whereas similar excesses of lysine, tryptophan, and threonine were far less toxic.

The Met requirement of Chinese yellowed-feathered chicks (unsexed) was $0.46 \%$ at the starter phase, according to the old estimations of [16]. According to the results here, however, the Met requirement of Chickens differed between males and females. These results agree with previous findings $[4,5,17]$, which indicated that chicken males and females have different Met requirements. In the present study, the estimated Met requirements of male and female Lingnan, and male Guangxi chickens, determined according to EA and QP models, were higher than the old recommended level $(0.46 \%)$ of FSC [16]; but the estimated Met requirement of female Guangxi chicken was lower than the recommended value [16]. According to NRC [27], the requirements of Met and Met + Cystine for commercial broiler chickens during the starter period (0-3 weeks) are $0.5 \%$ and $0.9 \%$ of the diet. The obtained Met requirements here were obtained in the presence of $0.26 \%$ cystine (Table 1 ) in the basal diet. The different Met requirements between breeds (fast and slow growing) or between both sexes is logically attributed to differences in growth rates and genetic potential [31]. Kalinowski et al. [24], reported that Ross 308 broilers optimized final BW (794 g) with dietary Met of 0.50\% during 0-21 days; whereas Xi et al. [5], found that the yellow-feathered chicken only needed $0.433-0.435 \%$ Met (male) and 0.445-0.454\% Met (female) for optimal 21 day BW (male: $351.12 \mathrm{~g}$; female:314.37 g) in the starter phase. According to the available information on the FSC [16] and feeding management regulations of the yellow feathered-chicken [15], the Lingnan chicken breed is classified as a fast-growing breed, and the Guanxi chicken is a slow-growing breed; this can explain the differences in Met requirements obtained here between the two breeds. The different starter phase durations of the Lingnan (0-21 days), and Guangxi (0-30 days) are originally dependent on their growth rate and genetic potential, which have caused the differences in the optimal Met requirement of the two breeds. Similar results were reported by Kalinowski et al. [24] and Dozier et al. [32]. Additionally, several studies indicated that evaluating the response of more than one variable to a dietary nutrient makes it difficult to determine a unique value of the nutrient requirement, i.e., the optimal level of any nutrient required for obtaining the best result of growth rate, body weight, feed intake, feed conversion ratio, meat quality, or immunity indices can differ [2,3,33]; this can explain the different values of optimal Met level for the different growth variables here. 


\section{Conclusions}

Supplementation of graded Met levels in basal diets of yellow feathered broilers during the starter period showed beneficial influences on their growth performance indices. The results indicated that the optimal Met requirement differed between the fast (up to $21 \mathrm{~d}$ of age) and slow-growing (up to 30 days of age) yellow-feathered chicken breeds as well as between males and females of each breed. The QP regression model was more appropriate for estimating the optimal Met requirements for the best body weight, average daily gain, feed intake and FCR indices of Lingnan (fast-growing) males $(0.52 \%$ to $0.58 \%$ ), females $(0.51 \%)$, and mixed genders $(0.53 \%)$, as well as for Guangxi (slow-growing) males $(0.53 \%)$, whereas the EA model was found to be better for estimating the optimal Met requirement of Guangxi females (0.43\%) and mixed genders (0.48\% to $0.49 \%)$.

Author Contributions: L.L., K.F.M.A., Z.C., A.E.G.G.-E., Q.F., F.D., and J.G., participated in acquisition of data, and analysis and/or interpretation of data; L.L., K.F.M.A., A.E.G.G.-G., S.J., and Z.J., participated in drafting the manuscript; S.J. and Z.J. participated in fund acquisition. All authors have read and agreed to the published version of the manuscript.

Funding: This study was supported by National Key R\&D Project (2018 YFD0500600), National Natural Science Foundation of China (31802104), Presidential Foundation of the Guangdong Academy of Agricultural Sciences, P. R. China (201810B), the Natural Science of Guangdong Province (2017A030310096), the "Twelve-Five" National Science and Technology Support Program (2014BAD13B02), Earmarked Fund for Modern Agro-industry Technology Research System (CARS-41) from the Ministry of Agriculture, Scientific and Technological Project (2017B020202003) from the Department of Science and Technology of Guangdong Province, and Grant No. 201804020091 from Guangzhou Science Technology and Innovation Commission, Presidential Foundation of the Guangdong Academy of Agricultural Sciences (201620, 201805, 201807B, 201809B and 201908), PR China. The Outstanding Talents Training Program of Guangdong Academy of Agricultural Sciences; Operating Funds for Guangdong Provincial Key Laboratory of Animal Breeding and Nutrition (2014B030301054; Supporting Program for Guangdong Agricultural Research \& Development Center of Livestock and Poultry Healthy Breeding.

Conflicts of Interest: The authors declare no conflict of interest.

\section{References}

1. Jiang, S.; Gou, Z.; Li, L.; Lin, X.; Jiang, Z. Growth performance, carcass traits and meat quality of yellowfeathered broilers fed graded levels of alfalfa meal with or without wheat. Anim. Sci. J. 2017, 89, 561-569. [CrossRef] [PubMed]

2. Li, L.; Abouelezz, K.F.M.; Gou, Z.; Lin, X.; Wang, Y.; Fan, Q.; Cheng, Z.; Ding, F.; Jiang, S.; Jiang, Z. Optimization of dietary zinc requirement for broiler breeder hens of chinese yellow-feathered chicken. Animals 2019, 9, 472. [CrossRef]

3. Abouelezz, K.F.M.; Wang, Y.; Wang, W.; Lin, X.; Li, L.; Gou, Z.; Fan, Q.; Jiang, S. Impacts of Graded Levels of Metabolizable Energy on Growth Performance and Carcass Characteristics of Slow-Growing Yellow-Feathered Male Chickens. Animals 2019, 9, 461. [CrossRef] [PubMed]

4. Xi, P.; Lin, Y.; Jiang, S.; Zheng, C.; Zhou, G.; Jiang, Z. Effects of dietary Methionine levels on growth performance, carcass quality, feather protein retention and meat quality in yellow-feathered broiler chickens aged from 43 to 63 days. Chin. J. Anim. Nutr. 2011, 23, 210-218.

5. Xi, P.; Lin, Y.; Zheng, C.; Jiang, S.; Zhou, G.; Jiang, Z. Digestible Methionine requirement of Yellow-feathered broiler chickens from 0 to 21 and 22 to 42 day of age. Chin. J. Anim. Sci. 2010, 46, 31-35.

6. Wisuttipongtarvorn, S. Methionine Requirement of Suwan-6 Crossbred Native Chicken at 0-6 Weeks of Age. 1994. Available online: http://agris.fao.org/agris-search/search.do?recordID=TH1998000282 (accessed on 18 January 2020).

7. Attia, Y.A.; Hassan, R.A.; Shehatta, M.H.; Abd El-Hady, S.B. Growth, carcass quality and blood serum constituents of slow growth chicks as affected by betaine additions to diets containing 2. Different levels of methionine. Int. J. Poult. Sci. 2005, 4, 856-865.

8. Attia, Y.A. Responses of growth performance, carcass characteristics, meat quality and plasma constituents of male Campbell ducks to dietary levels of methionine and phytase and their interactions. Egypt. Poult. Sci. J. 2003, 23, 557-580. 
9. Wen, C.; Jiang, X.Y.; Ding, L.R.; Wang, T.; Zhou, Y.M. Effects of dietary methionine on growth performance, meat quality and oxidative status of breast muscle in fast- and slow-growing broilers. Poult. Sci. 2017, 96, 1707-1714. [CrossRef]

10. Chen, Y.P.; Chen, X.; Zhang, H.; Zhou, Y.M. Effects of dietary concentrations of methionine on growth performance and oxidative status of broiler chickens with different hatching weight. Br. Poult. Sci. 2013, 54, 531-537. [CrossRef]

11. Rama Rao, S.V.; Praharaj, N.K.; Reddy, M.R.; Panda, A.K. Interaction between genotype and dietary concentrations of methionine for immune function in commercial broilers. Br. Poult. Sci. 2003, 44, 104-112. [CrossRef]

12. Shini, S.; Li, X.; Bryden, W.L. Methionine requirement and cell-mediated immunity in chicks. Br. J. Nutr. 2005, 94, 746-752.

13. Martínez, Y.; Li, X.; Liu, G.; Bin, P.; Yan, W.; Más, D.; Valdivié, M.; Hu, C.A.; Ren, W.; Yin, Y. The role of methionine on metabolism, oxidative stress, and diseases. Amino Acids 2017, 49, 2091-2098. [CrossRef] [PubMed]

14. Soares, M.S.; Oliveira, P.S.; Debom, G.N.; da Silveira Mattos, B.; Polachini, C.R.; Baldissarelli, J.; Morsch, V.M.; Schetinger, M.R.; Tavares, R.G.; Stefanello, F.M.; et al. Chronic administration of methionine and/or methionine sulfoxide alters oxidative stress parameters and ALA-D activity in liver and kidney of young rats. Amino Acids 2017, 49, 129-138. [CrossRef] [PubMed]

15. Ministry of Agriculture, China. Feeding Management Regulations of Yellow Feathered-Chicken, 1st ed.; Standards Press of China: Beijing, China, 2010.

16. Ministry of Agriculture, China. Feeding Standard of Chicken, 1st ed.; Standards Press of China: Beijing, China, 2004.

17. Xi, P.B.; Yi, G.F.; Lin, Y.C.; Zheng, C.T.; Jiang, Z.Y.; Song, G.L.; Knight, C.D. Effect of methionine source and dietary crude protein level on growth performance, carcass traits and nutrient retention in Chinese color-feathered chicks. AJAS 2007, 20, 962-970. [CrossRef]

18. Pesti, G.M.; Vedenov, D.; Cason, J.A.; Billard, L.A. Comparison of methods to estimate nutritional requirements from experimental data. Br. Poult. Sci. 2009, 50, 16-32. [CrossRef] [PubMed]

19. Robbins, K.R.; Saxton, A.M.; Southern, L.L. Estimation of nutrient requirements using broken-line regression analysis. J. Anim. Sci. 2006, 84, 155-165. [CrossRef]

20. Mayer, A.N.; Vieira, S.L.; Berwanger, E.; Angel, C.R.; Kindlein, L.; França, I.; Noetzold, T.L. Zinc requirements of broiler breeder hens. Poul. Sci. 2019, 98, 1288-1301. [CrossRef]

21. Leeson, S.; Zubair, A. Nutrition of the broiler chicken around the period of compensatory growth. Poult. Sci. 1997, 76, 992-999. [CrossRef]

22. Motl, M.A.; Fritts, C.A.; Waldroup, P.W. Influence of Dietary Sodium Level on Utilization of Methionine from DL-Methionine and Liquid Methionine-Hydroxy Analogue. J. Appl. Poult. Res. 2005, 14, 147-155. [CrossRef]

23. Liu, Y.L.; Song, G.L.; Yi, G.F.; Hou, Y.Q.; Huang, J.W.; Knight, C.D. Effect of supplementing 2-hydroxy-4-(methylthio) butanoic acid and DL-methionine in corn-soybean-cottonseed meal diets on growth performance and carcass quality of broilers. AJAS 2006, 19, 1197-1205. [CrossRef]

24. Kalinowski, A.; Moran, E.; Wyatt, C. Methionine and cystine requirements of slow- and fast-feathering male broilers from zero to three weeks of age. Poult. Sci. 2003, 82, 1423-1427. [CrossRef] [PubMed]

25. Tsiagbe, V.K.; Cook, M.E.; Harper, A.E.; Sunde, M.L. Enhanced immune-responses in broiler chicks fed methionine-supplemented diets. Poult. Sci. 1987, 66, 1147-1154. [CrossRef] [PubMed]

26. Carew, L.B.; McMurtry, J.P.; Alster, F.A. Effects of methionine deficiencies on plasma levels of thyroid hormones, insulin-like growth factors-I and -II, liver and body weights, and feed intake in growing chickens. Poult. Sci. 2003, 82, 1932-1938. [CrossRef] [PubMed]

27. National Research Council. Nutrient Requirements of Poultry; National Academies Press: Washington, WA, USA, 1994.

28. Jamroz, D.; Wiliczkiewicz, A.; Lemme, A.; Orda, J.; Skorupińska, J.; Wertelecki, T. Effect of increased methionine level on performance and apparent ileal digestibility of amino acids in ducks. J. Anim. Phys. Anim. Nutr. 2009, 93, 622-630. [CrossRef] [PubMed]

29. D'Mello, J.P.F.; D'Mello, J. An outline of pathways in amino acid metabolism. In Amino Acids in Animal Nutrition; CABI Publishing: Wallingford, UK, 2003; pp. 71-86. 
30. Edmonds, M.S.; Baker, D.H. Comparative effects of individual amino acid excesses when added to a corn-soybean meal diet: Effects on growth and dietary choice in the chick. J. Anim. Sci. 1987, 65, 699-705. [CrossRef] [PubMed]

31. Sokołowicz, Z.; Krawczyk, J.; Świątkiewicz, S. Quality of Poultry Meat from Native Chicken Breeds-A Review. Ann. Anim. Sci. 2016, 16, 347-368. [CrossRef]

32. Dozier, W.A.; Moran, E.T.; Kidd, M.T. Responses of Fast- and Slow- Feathering Male Broilers to Dietary Threonine During 42 to 56 Days of Age. J. Appl. Poult. Res. 2000, 9, 460-467. [CrossRef]

33. Xia, W.G.; Chen, W.; Abouelezz, K.F.; Azzam, M.M.; Ruan, D.; Wang, S.; Zhang, Y.N.; Luo, X.; Wang, S.L.; Zheng, C.T. Estimation of calcium requirements for optimal productive and reproductive performance, eggshell and tibial quality in egg-type duck breeders. Animal 2019, 13, 2207-2215. [CrossRef]

(C) 2020 by the authors. Licensee MDPI, Basel, Switzerland. This article is an open access article distributed under the terms and conditions of the Creative Commons Attribution (CC BY) license (http://creativecommons.org/licenses/by/4.0/). 